\title{
Margaret McCartney: Can't we take mental illness seriously without Prince Harry?
}

\author{
Margaret McCartney general practitioner
}

Glasgow

For over 400 years, monarchs such as Henry VII touched the face or neck of people with scrofula. This disease-tuberculous cervical lymphadenitis—was also known as "the King's evil." It often improved anyway, giving the impression that unquestioned authority and ritual could do miracles. ${ }^{1}$

George I ended the practice, and royal touches now involve flashes of media magic. Prince Harry scored global headlines by stating that he sought counselling after his mother's death.

This has been broadly viewed as brilliant advocacy for de-stigmatising mental distress and encouraging people to talk. Such is Harry's reach that Simon Wessely, president of the Royal College of Psychiatrists, thinks that "in just 25 minutes he has achieved more good than I have in 25 years."

Who can fail to like someone willing to play an innocent game of strip billiards, or to feel sorry when previous mistakes and indiscretions are plastered on global front pages? It's not Harry's fault that he was born into privilege, or that the population finds the monarchy's personal lives fascinating.

Paradoxically, the lack of privacy that makes him well known and his declaration newsworthy may have also contributed to the distress he disclosed. Personal tragedy lived in public has its own stresses.

Urging people to talk about mental distress is one thing, but what comes next? Celebrities have publicised episodes of mental illness for decades, and I don't see meaningful investment in services. In fact, $57 \%$ of clinical commissioning groups plan to decrease spending on mental health services. ${ }^{3}$

Our benefits system has discriminated against people with mental illness and is associated with an increase in suicides and self reported mental health problems. ${ }^{45}$ Inpatient beds are lacking — meaning many admissions to hospital miles away—as are suitable facilities in the community, including housing, to discharge people to. ${ }^{6}$

If poor, illiterate patients don't have a ferocious advocate they may simply drop off the waiting list altogether
Talking among ourselves won't sort out these enormous problems. If I refer someone with a suspected cancer they'll be seen within two weeks. Not only will their times to treatment be researched and audited but they may have a specialist nurse to support them. They may also have a dedicated charity worker to ensure that they get the benefits they're entitled to.

If my patient, however, has anorexia or depression or-totally flummoxing the system-psychosis in addition to drug or alcohol addiction, things are different. Patients can bounce painfully between the walls of departments, which too often seem designed to keep people out.

It's understandable: departments are underfunded and overstretched. If poor, illiterate patients don't have a ferocious advocate and can't, for example, keep phoning back a service to confirm that they really still need to be seen, they may simply drop off the waiting list altogether.

If waiting lists to be admitted for cancer treatment were as long as those for treating alcoholism, we'd be outraged. Instead, there's a quiet acceptance that this is just how it is.

The king's touch, when it worked, turned out to be a coincidence or a placebo effect. Harry has done a good thing. But not all medical suggestions by the monarchy should be acted on-homeopathy, especially—and it seems dangerous to rely on the good will of well known people to overturn systemic problems in a nationally funded health and social care service. Strong pressure is needed to take mental illness as seriously as any other, but it must be matched by financial commitment to actually ensure that it happens. Celebrities may help, but shouldn't we make sure that they aren't needed?

Competing interests: See www.bmj.com/about-bmj/freelancecontributors/margaret-mccartney.

Provenance and peer review: Commissioned; not externally peer reviewed.

Follow Margaret on Twitter, @mgtmccartney 
1 Brogan S. The royal touch in early modern England: politics, medicine and sin. Royal Historical Society Studies, 2015. https://boydellandbrewer.com/the-royal-touch-in-earlymodern-england-hb.html.

2 Wessely S. Price Harry's words are simple, true ... and remind us that this is just normal. Daily Telegraph 16 Apr 2017. www.telegraph.co.uk/news/2017/04/16/prince-harrys-wordssimple-true-remind-us-just-normal/.

3 Full Fact. Spending on mental health services. 26 Oct 2016. https://fullfact.org/health/ spending-mental-health-services/.

4 Gentleman A. Fitness for work tests unfair to those with mental health problems, court says. Guardian 22 May 2013. https://www.theguardian.com/society/2013/may/22/fitnesswork-tests-mental-health-unfair.
5 Barr B, Taylor-Robinson D, Stuckler D, Loopstra R, Reeves A, Whitehead M. 'First, do no harm': are disability assessments associated with adverse trends in mental health? A longitudinal ecological study. J Epidemiol Community Health 2016;357:339-45. doi:10. longitudinal ecological study. J Epidemiol

6 Royal College of Psychiatrists. Independent commission report highlights reasons for bed shortages. 15 Jul 2015. www.rcpsych.ac.uk/mediacentre/pressreleases2015/ commissionreport2015.aspx.

Published by the BMJ Publishing Group Limited. For permission to use (where not already granted under a licence) please go to http://group.bmj.com/group/rights-licensing/ permissions 